\begin{tabular}{ccc|} 
PEDIOMATERNAL \\
NURSING JOURNAL \\
Vol. 7, No. 2, September 2021 \\
Journal Homepage: https://e-journal.unair.ac.id/PMNJ/ \\
http://dx.doi.org/10.20473/pmnj.v7i2.27501
\end{tabular}

Review

\title{
Prevalence and Factors Affecting the Labor Experience: A Systematic Review
}

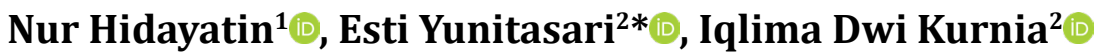 \\ ${ }^{1}$ Master in Nursing Study Program, Faculty of Nursing, Universitas Airlangga, Surabaya, Indonesia \\ ${ }^{2}$ Department of Fundamental Nursing, Faculty of Nursing, Universitas Airlangga, Surabaya, Indonesia
}

\section{ARTICLE HISTORY}

Received : June 14, 2021

Revised : July 13, 2021

Accepted : September 8, 2021

Published : September 15, 2021

\section{KEYWORDS}

childbirth; experience; factors; prevalence

\section{CORRESPONDING AUTHOR}

*Esti Yunitasari

esti-y@fkp.unair.ac.id

Department of Fundamental

Nursing, Faculty of Nursing,

Universitas Airlangga,

Surabaya, Indonesia

\begin{abstract}
Introduction: Labor experiences have potential short and long term physical and psychological effects on women's lives. Many factors influenced role in a mother's experience of childbirth, both positively and negatively. This study aimed to determine the prevalence and factors that influence the delivery experience.

Methods: This study searched for articles in the databases, namely Pub Med, Scopus, ProQuest, ScienceDirect, and Sage. The keyword used is labor experience. A total of 3654 articles were found, after selecting studies using PRISMA found 18 corresponding articles.

Results: In this study, 18 studies were included in this systematic review, eight studies examined the prevalence of labor experiences. The prevalence of labor experience was $6.8-44 \%$. Factors related to childbirth experiences included: individuals, such as age, parity, fear, self-efficacy, participation, control, expectations, preparation, and interpersonal, such as husband support, caregiver support, unwanted medical problems, such as prolonged labor, stimulation, and induction, forceps delivery, emergency cesarean section, and use of analgesics in mothers, low APGAR scores and transfer to the NICU.

Conclusion: This review showed the various factors associated with the childbirth experience. This finding suggests conducting further research into the reason these factors influence the experience of labor.
\end{abstract}

Hidayatin, N., Yunitasari, E., \& Kurnia, I, D. (2021). Prevalence and Factors Affecting the Labor Experience: A Systematic Review. Pediomaternal Nurs. J., 7(2), 84-91. Doi: http://dx.doi.org/10.20473/pmnj.v7i2.27501

\section{INTRODUCTION}

Pregnancy and childbirth are physiological processes that are important and natural in every woman life and her family (Dahlberg et al., 2016). The physiology of childbirth is the same for all women, but understanding childbirth varies widely among different people. Understanding childbirth is influenced by cultural beliefs, traditions, and many other variables, and it is unique and specific to each woman (Mukamurigo et al., 2017). Childbirth and its associated experiences have potential physical and psychological effects on a woman's short and long term life.

The inclusive goal of caring for women during childbirth is to create positive experiences for them and their families while observing their physical and mental health, preventing complications, deaths, 
and emergency cases (Henriksen et al., 2017). Suppose the experience of childbirth is a positive perception. In that case, it can increase the amount of patience, responsibility, self-esteem, self-efficacy, self-sufficiency, and independence of the mother, improve the quality of life of women with better relationships between mother and baby, and generally empower women (Howarth \& Swain, 2019). Empowering women makes them more involved in taking care of themselves and their children and controlling and managing other challenges (Karlström et al., 2015).

Many factors play an influential role in both positive and negative maternal experiences. Several studies have examined the factors that influence the experience of childbirth. Take into account the short-term and long-term physical and psychological importance. In addition, the effect of childbirth on women and the influence of different variables on the conception and experience of women's labor need to be explored. This study aims to examine the prevalence and factors that influence childbirth experience so that planning and strategies are appropriate (Hassanzadeh et al., 2020).

\section{METHODS}

This systematic review included five steps: formulating questions, identifying relevant databases, assessing the quality of papers based on a checklist, summarizing results, interpreting findings (discussion). In addition, this assessment evaluated the methodological quality of a study and determined the extent to which a study has addressed possible biases in its design, implementation, and analysis.

\section{Formulation of Questions}

The questions formulated for this systematic review are: What is the prevalence of negative childbirth experiences and the factors related to the birth experience?

\section{Identify relevant databases}

This research was conducted by searching for articles in the Scopus, Sage, Science direct, Ebsco, and ProQuest databases, with the following keywords: Mother, Childbirth, Postpartum, Normal Delivery, Birth Experience, Positive and Negative Perceptions.
A randomized search evaluation was published in English.

Article searches are carried out using keywords and Boolean operators (AND, OR NOT, or AND NOT) to determine the search to obtain articles that match the research objectives. The search strategy was defined as woman OR Mother AND Childbirth OR Birth OR Childbirth OR Childbirth OR Childbirth AND Vaginal Delivery OR Normal Labor OR Vaginal OR Natural Labor - Experience OR Perception AND Positive and Negative.

\section{Selection of articles}

Full text or abstracts of all articles were documented from extracted search results. The researcher carefully studies the full text of the articles, and the related articles are selected, and then irrelevant items are excluded.

\section{Inclusion and exclusion criteria}

The inclusion criteria for the articles were all articles related to the experience of giving birth to women, which were published in the last ten years and are original articles. The exclusion criteria are articles in systematic reviews.

\section{RESULTS}

During the initial search through different databases, 3654 articles were found, 1784 articles were duplicated due to database overlap. Among the remaining 1852 articles, 1304 articles were excluded after reviewing the article titles and abstracts. Among the remaining 548 articles, 528 articles were excluded because the subjects were not relevant to the purpose of this study, and finally, 18 papers remained. In these 18 articles, eight studies examined the prevalence of childbirth experiences, and 18 studies examined the factors that influence childbirth experience.

The table 1 is basic characteristics of the included studies.

Of the eight studies, three studies conducted by Waldenstrom et al., the results of the first study showed that the prevalence of positive experiences was $71.1 \%$. The second study results were the prevalence of non-positive post-partum experiences 28.9\% (negative experiences 7.1\%). The third study results showed that positive experiences amounted to $88.2 \%$ and negative experiences 


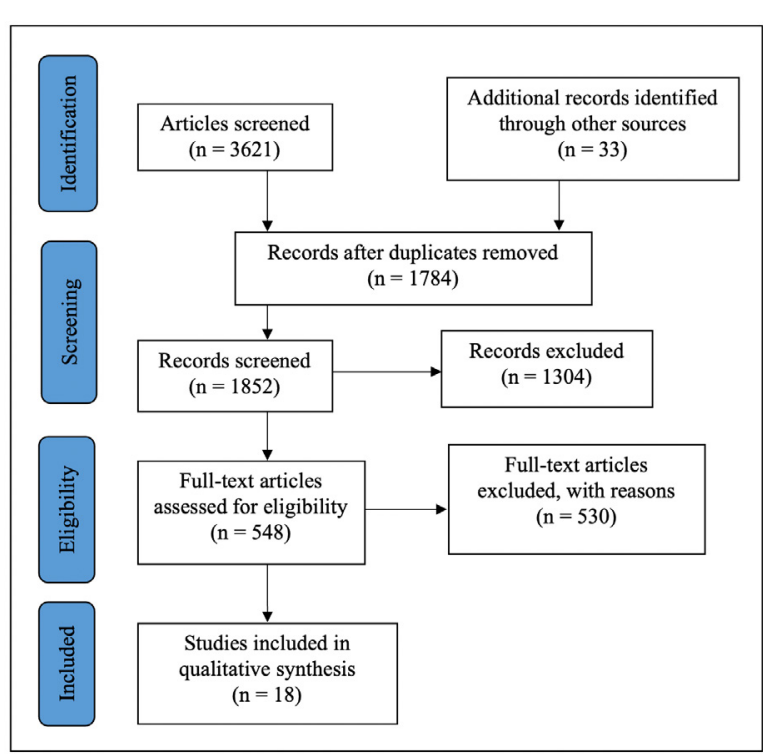

Figure 1. Flow diagram showing the selection process of articles for systematic review

by $10.4 \%$. In a study conducted by Gottvall and Waldenstrom, they examined the individual delivery experiences of 617 nulliparous women in Sweden. They found that the prevalence of positive experiences was $88.2 \%$ and negative experiences $11.8 \%$ (Waldenström et al., 2004).

A Canadian study conducted by Smarandache et al. reported a $90.7 \%$ prevalence of positive experiences and 9.3\% negative experiences (Smarandache et al., 2016). Another study in Norway conducted by Henriksen et al. showed that the prevalence of positive experiences was $78.9 \%$, and negative experiences were $21.1 \%$ (Henriksen et al., 2017). Another study conducted by Ulfsdottir et al. in Sweden found a prevalence of positive experiences $56 \%$ negative experiences $44 \%$ (Ulfsdottir et al., 2014). In Rwanda, a study conducted by Mukamurigo et al. reported a prevalence of positive experiences of $77.5 \%$ non-positive experiences of $22.5 \%$ (Mukamurigo et al., 2017).

\section{Factors related to the experience of childbirth}

Of 18 articles reviewed, the factors associated with the experience of childbirth can be categorized into three categories: individual, interpersonal factors and unexpected medical problems.

\section{Individual Factors}

\section{Demographic factors}

Age

Different results were obtained in terms of age in the articles reviewed. In the Smarandache et al. study, negative experiences were higher in older women. In Al Ahmar and Tarraf's study, older women ( $>38$ years) were more satisfied with their delivery experience. In a study conducted by Waldenstrom et al. in different years, there was no relationship between age and delivery experience (Al Ahmar \& Tarraf, 2014; Waldenström et al., 2004).

\section{Afraid}

Two studies showed there was a link between fear and negative childbirth experiences. First, a study by Elvander found that women with moderate and high levels of fear, had higher rates of cesarean delivery and emergency deliveries than women with lower levels of fear, resulting in more negative experiences (Elvander et al., 2013).

\section{Self Efficacy}

This review showed that the level of self-efficacy decreases with increasing fear of pregnant women. Furthermore, this fear and decreased self-efficacy have been accompanied by an increase in negative childbirth experiences (Azmoude et al., 2017).

\section{Participation}

Researchers suggested in their study that women's participation and involvement in the labor process would reduce negative experiences of childbirth and increase women's satisfaction during delivery (Neerland et al., 2020).

\section{Control}

This review showed that seven studies reported an association between control and delivery experience. These studies determined that the higher the control of women in labor, the lower their negative childbirth experience, so that pain will be more tolerable and their labor more pleasant (Henriksen et al., 2020).

\section{Hope}

The results indicated that women whose expectations have been met tend to have negative childbirth experiences, indicating 
Table 1. Primary characteristics of the included studies

\begin{tabular}{|c|c|c|c|}
\hline $\begin{array}{c}\text { Ref e r e n c e / } \\
\text { country }\end{array}$ & Aim of study & Study design & Sample size \\
\hline Sweden & $\begin{array}{l}\text { Increase our understanding of wom- } \\
\text { en's birth experience by studying the } \\
\text { association between selected and } \\
\text { women's rating of their overall birth } \\
\text { experience two months after giving } \\
\text { birth }\end{array}$ & $\begin{array}{l}\text { Prospective co- } \\
\text { hort study }\end{array}$ & $\begin{array}{l}1111 \text { women who participated in a } \\
\text { birth center trial }\end{array}$ \\
\hline Gothenburg & $\begin{array}{l}\text { Clarify different aspects of the birth ex- } \\
\text { perience and to } \\
\text { identify factors that could explain the } \\
\text { variation in } \\
\text { women's overall assessment of it }\end{array}$ & $\begin{array}{l}\text { Prospective co- } \\
\text { hort study }\end{array}$ & $\begin{array}{l}295 \text { women, } 47.5 \% \text { were primiparas } \\
\text { and } \\
52.5 \% \text { multiparas }\end{array}$ \\
\hline Sweden & $\begin{array}{l}\text { The prevalence of a negative birth ex- } \\
\text { perience one year after the birth in a } \\
\text { national sample of Swedish-speaking } \\
\text { women and to identify predictors of a } \\
\text { negative experience }\end{array}$ & $\begin{array}{l}\text { Longitudinal } \\
\text { cohort study }\end{array}$ & $\begin{array}{l}2541 \text { women recruited from all ante- } \\
\text { natal clinics in Sweden during three } \\
\text { weeks spread over one year was con- } \\
\text { ducted }\end{array}$ \\
\hline Sweden & $\begin{array}{l}\text { To investigate whether women's expe- } \\
\text { riences of their first birth affects future } \\
\text { reproduction }\end{array}$ & $\begin{array}{l}\text { Prospective co- } \\
\text { hort study }\end{array}$ & $\begin{array}{l}617 \text { women who gave birth to their } \\
\text { first child }\end{array}$ \\
\hline Canada & $\begin{array}{l}\text { Assess the prevalence of, and identify } \\
\text { the risk factors associated with a neg- } \\
\text { ative birth experience for women in } \\
\text { Canada }\end{array}$ & Cross-sectional & $\begin{array}{l}\text { On First Nations reserves or in insti- } \\
\text { tutions were excluded. A stratified } \\
\text { random sample of } 8542 \text { women was } \\
\text { selected from the } 2006 \text { Canadian } \\
\text { population census, and } 6421 \text { eligible } \\
\text { women }(75.2 \%) \text { responded. }\end{array}$ \\
\hline Norwegian & $\begin{array}{l}\text { Explore factors associated with a neg- } \\
\text { ative birth experience among Norwe- } \\
\text { gian women }\end{array}$ & $\begin{array}{l}\text { Mixed methods } \\
\text { (cohort of the } \\
\text { Bidens study) }\end{array}$ & $\begin{array}{l}1352 \text { Norwegian multiparous wom- } \\
\text { en }\end{array}$ \\
\hline Sweden & $\begin{array}{l}\text { Study well-known as well as new fac- } \\
\text { tors associated with a negative expe- } \\
\text { rience of childbirth among a group of } \\
\text { healthy primiparas }\end{array}$ & $\begin{array}{l}\text { Prospective co- } \\
\text { hort study }\end{array}$ & 446 healthy primiparas \\
\hline Rwanda & $\begin{array}{l}\text { To investigate how women's overall } \\
\text { childbirth experience in Rwanda was } \\
\text { related to their perceptions of child- } \\
\text { birth care }\end{array}$ & $\begin{array}{l}\text { Cross-sectional } \\
\text { household }\end{array}$ & $\begin{array}{l}921 \text { women had given birth } 1-3 \\
\text { months earlier }\end{array}$ \\
\hline Pennsylvania & $\begin{array}{l}\text { Estimate the effects of different levels } \\
\text { of fear of birth and mode of delivery on } \\
\text { birth experience one month after birth }\end{array}$ & $\begin{array}{l}\text { Prospective } \\
\text { study }\end{array}$ & $\begin{array}{l}\text { Which included } 3006 \text { English and } \\
\text { Spanish speaking, nulliparous wom- } \\
\text { en aged 18-35 years in Pennsylvania }\end{array}$ \\
\hline $\begin{array}{l}\text { Rijnders Nether- } \\
\text { lands }\end{array}$ & $\begin{array}{l}\text { Investigate Dutch women's views of } \\
\text { their birth experience three after the } \\
\text { event }\end{array}$ & Cross-sectional & 1309 postnatal \\
\hline Canada & $\begin{array}{l}\text { To summarize what is known about } \\
\text { satisfaction with childbirth, with par- } \\
\text { ticular attention to the roles of pain } \\
\text { and pain relief }\end{array}$ & Cross-sectional & $\begin{array}{l}137 \text { reports of factors influencing } \\
\text { women's evaluations of their child- } \\
\text { birth experiences }\end{array}$ \\
\hline Columbia & $\begin{array}{l}\text { To examine multiple factors for their } \\
\text { association with components of child- } \\
\text { birth satisfaction and with the total } \\
\text { childbirth experience }\end{array}$ & $\begin{array}{l}\text { Correlatioal de- } \\
\text { scriptive study }\end{array}$ & $\begin{array}{l}60 \text { low-risk post-partum women, } \\
\text { aged } 18-46 \text { years }\end{array}$ \\
\hline Canadian & $\begin{array}{l}\text { To determine the factors that predict } \\
\text { women's perceptions of the childbirth } \\
\text { experience and to examine wheth- } \\
\text { er these vary with the type of birth a } \\
\text { woman experiences }\end{array}$ & $\begin{array}{l}\text { Prospective co- } \\
\text { hort study }\end{array}$ & 652 women and their newborns \\
\hline
\end{tabular}


Table 1. Primary characteristics of the included studies (Continue)

\begin{tabular}{|c|c|c|c|}
\hline $\begin{array}{c}\text { Ref e r e n c e / } \\
\text { country }\end{array}$ & Aim of study & Study design & Sample size \\
\hline Sweden & $\begin{array}{l}\text { To evaluate the impact of personality, } \\
\text { sociodemographic and obstetric fac- } \\
\text { tors on birth experience in a cohort of } \\
\text { healthy first-time mothers }\end{array}$ & Cross-sectional & $\begin{array}{l}541 \text { women were prospectively fol- } \\
\text { lowed from the end of pregnancy un- } \\
\text { til nine months post-partum }\end{array}$ \\
\hline US & $\begin{array}{l}\text { Identify factors associated with confi- } \\
\text { dence and positive experiences during } \\
\text { birth among a national sample of US } \\
\text { mothers }\end{array}$ & Mix method & $\begin{array}{l}\text { A nationally representative sam- } \\
\text { ple of women gave birth in } 2005 \\
\text { to a singleton baby in a US hospital } \\
(\mathrm{N}=1573) \text {. }\end{array}$ \\
\hline Lebanon & $\begin{array}{l}\text { To assess which socio-demographic } \\
\text { factors are associated with this satis- } \\
\text { faction. }\end{array}$ & $\begin{array}{l}\text { Cross-sectional } \\
\text { study }\end{array}$ & $\begin{array}{l}\text { The sample consisted of } 100 \text { women } \\
\text { who had given birth in the past three } \\
\text { days before the interview. }\end{array}$ \\
\hline Tehran & $\begin{array}{l}\text { Determine the satisfaction degree of } \\
\text { normal delivery and its relative factors } \\
\text { in childbearing women at "Shaheed } \\
\text { Chamran, Borujerd" and "Madiye, Teh- } \\
\text { ran" Hospitals }\end{array}$ & $\begin{array}{l}\text { Descriptive cor- } \\
\text { relative study }\end{array}$ & $\begin{array}{l}360 \text { literate Iranian childbearing } \\
\text { mothers were chosen via a non-prob- } \\
\text { able quota sampling }\end{array}$ \\
\hline $\begin{array}{l}\text { Belgian and } \\
\text { Netherlands }\end{array}$ & $\begin{array}{l}\text { The purpose of our study is to assess } \\
\text { the influence of expectations about } \\
\text { childbirth, labor pain, personal control } \\
\text { and self-efficacy on Belgian and Dutch } \\
\text { women's satisfaction with childbirth }\end{array}$ & $\begin{array}{l}\text { Cross-national } \\
\text { perspective }\end{array}$ & $\begin{array}{l}605 \text { women, one at } 30 \text { weeks of preg- } \\
\text { nancy and one within the first two } \\
\text { weeks after childbirth }\end{array}$ \\
\hline
\end{tabular}

realistic expectations (Karlström et al., 2015).

\section{Preparation}

Women who are ready to give birth, have labor scheduled, and are intentionally pregnant, have a more positive and enjoyable labor experience (Hassanzadeh et al., 2020; Henriksen et al., 2017).

\section{Interpersonal factors}

\section{Husband's support}

The articles reviewed also showed that women's support from husbands reduced negative childbirth experiences and increased women's satisfaction with childbirth (Hildingsson, 2017).

\section{Care provider support}

Care provider support such as sufficient time allocated for women and support during delivery enhances positive delivery experiences (Dahlberg et al., 2016).

\section{Unexpected medical problems}

\section{Mother}

A review of various studies showed that unexpected medical problems in mothers, such as prolonged labor, stimulation and induction, forceps delivery, emergency cesarean section, and analgesics in labor (epidurals and pethidine), have led to negative experiences in women (Baldino et al., 2020).

\section{Child}

Unexpected problems for the baby, including a low Apgar score and being transferred to the NICU, can lead to negative experiences. Conversely, touching the baby immediately after birth increases the level of positive experiences (Desmawati et al., 2020).

\section{DISCUSSION}

This study aimed to estimate the prevalence of negative post-partum experiences and associated factors. The cases that have proven effective in differing research results are:

The studies used different questionnaires, different ranking and scoring methods in the questionnaires in the study. For example, in the study of Waldenstrom et al., the overall experience of childbirth was evaluated. Responses were expressed on a 7-point scale; a score of 1 is considered very negative, and seven is considered very favourable. They rated 1-5 as non-positive experiences and perceived 6-7 as positive experiences (Waldenström et al., 2004).

In a study of the delivery experiences of 617 nulliparous women, answers were rated on a 7-option Likert scale. In this study, scores 1 and 2 were negative experiences, and 
3-7 were considered positive experiences. In the study conducted by Smarandache et al., answers are evaluated on a 5-point Likert scale; 1 and 2 are negative scores and scores 3-5 are considered positive experiences. The study of Mukamurigo et al., responses were classified from very bad experience with a score of 0 to very good experience with a score of 10; a score of 8-10 is considered a good and positive experience $(77.5 \%)$ and a score of 7-0 is a bad or mixed experience (52.5\%) (Smarandache et al., 2016).

A prior study was carried out on 1352 multiparous Norwegian women in which their first and last birth experiences were evaluated. The result was "Completely positive, moderately positive with negative elements, completely negative with positive elements, completely negative;" completely negative women with positive elements, negative responses are all considered negative experiences (Henriksen et al., 2017).

The result showed different study conditions, including sample size and characteristics. With a large sample size, relevant research results will be more precise. There was a difference between nulliparous and multiparous women, meaning that parity affects a woman's delivery experience. Negative experiences are more common in nulliparous women, indicating fear and anxiety in them (Levett et al., 2020). The experience of giving birth to women was evaluated at different post-partum periods. This act was conducted to examine the prevalence of childbirth experiences at different times of the puerperium.

Related factors in this review showed conflicting results concerning the relationship between age and labor experience. Women over the age of 30 had twice as many negative experiences as younger women. Older women are more satisfied with their deliveries. On the other hand, there was no relationship between age and childbirth experience (Sbrilli et al., 2020; Howarth \& Swain, 2019). The cause of this inconsistency could be due to differences in the number of samples, the method of sampling, the type of questionnaire used, and times the post-partum experience was checked. Further studies were needed with a more significant number of samples and the appropriate time.
Women's physical and mental preparation is beneficial for enhancing a positive labor experience; this physical and psychological preparation can make them confident about coping with childbirth (Henriksen et al., 2017). Women can be prepared by attending childbirth classes or by receiving information from mothers, relatives, the mass media, and direct observation of childbirth. This information includes labor and obstetric problems (prolonged labor), labor techniques (breathing and relaxation).

This study found that women with high self-efficacy had reduced pain and stress and increased satisfaction during childbirth. Bandura's defines self-efficacy as an individual's belief in his or her ability to succeed in a particular position (Puspasari et al., 2018; Bandura, A, 2010). In studies, women claim that being confident about their abilities and strength will control their pain and problems.

In this study, one factor that had a significant effect on negative experiences was prolonged labor. Stress and anxiety are one of the causes of prolonged labor. In cases of anxiety and stress, epinephrine levels increase, leading to decreased uterine activity and prolonged labor. Hence, women who are more afraid of labor are more likely to give birth by forceps, emergency cesarean delivery and analgesic use, resulting in a higher rate of negative labor experiences (Hassanzadeh et al., 2020).

In this study, the infant's low Apgar score and transfer to the NICU negatively affected, and direct contact with the mother led to a positive labor experience. In the study of Hardin et al., women define having a healthy baby as a positive experience (Desmawati et al., 2020).

\section{CONCLUSIONS}

This review shows that different countries use various tools to examine the experience of childbirth, so it is necessary to provide standard mechanisms for accurately estimating the experience of giving birth to women. With this research, it can be seen the factors that can influence childbirth and how to handle it properly to deliver well. 


\section{REFERENCES}

Al Ahmar, E., \& Tarraf, S. (2014). Assessment of the Socio-Demographic Factors Associated with the Satisfaction Related to the Childbirth Experience. Open Journal of Obstetrics and Gynecology, 04(10), 585-611. https://doi. org/10.4236/ojog.2014.410083

Azmoude, E., Farkhondeh, F., Ahour, M., \& Kabirian, M. (2017). Knowledge, practice and self-efficacy in evidencebased practice among midwives in East Iran. Sultan Qaboos University Medical Journal, 17(1), e66-e73. https://doi. org/10.18295/squmj.2016.17.01.012

Baldino, V. M. C. L., Eckert, G. U., Rossatto, J., \& Wagner, M. B. (2020). Red reflex test at the maternity hospital: results from a tertiary hospital and variables associated with inconclusive test results. Jornal de Pediatria, 96(6), 748-754. https://doi. org/10.1016/j.jped.2019.08.007

Bandura, A. (2010). Self Efficacy Mechanism in Psikological and Health Promoting Behavior.

Dahlberg, U., Persen, J., Skogås, A. K., Selboe, S. T., Torvik, H. M., \& Aune, I. (2016). How can midwives promote a normal birth and a positive birth experience? The experience of first-time Norwegian mothers. Sexual and Reproductive Healthcare, 7, 2-7. https://doi. org/10.1016/j.srhc.2015.08.001

Desmawati, Kongsuwan, W., \& Chatchawet, W. (2020). The effects of childbirth preparation nursing intervention integrating islamic praying program on duration of labor and neonatal outcomes in primiparous muslim women. Walailak Journal of Science and Technology, 17(10), 1048-1059. https://doi. org/10.48048/wjst.2020.5456

Elvander, C., Cnattingius, S., \& Kjerulff, K. H. (2013). Birth experience in women with low, intermediate or high levels of fear: Findings from the first baby study. Birth, 40(4), 289-296. https://doi. org/10.1111/birt.12065

Hassanzadeh, R., Abbas-Alizadeh, F., Meedya, S., Mohammad-Alizadeh-Charandabi, S., \& Mirghafourvand, M. (2020). Fear of childbirth, anxiety and depression in three groups of primiparous pregnant women not attending, irregularly attending and regularly attending childbirth preparation classes. BMC Women's Health, 20(1), 1-8. https://doi. org/10.1186/s12905-020-01048-9

Henriksen, L., Grimsrud, E., Schei, B., \& Lukasse, M. (2017). Factors related to a negative birth experience - A mixed methods study. Midwifery, 51, 33-39. https://doi. org/10.1016/j.midw.2017.05.004

Henriksen, L., Nordström, M., Nordheim, I., Lundgren, I., \& Blix, E. (2020). Norwegian women's motivations and preparations for freebirth-A qualitative study. Sexual and Reproductive Healthcare, 25(March), 100511. https://doi.org/10.1016/j. srhc.2020.100511

Hildingsson, I. (2017). Sense of coherence in pregnant and new mothers - A longitudinal study of a national cohort of Swedish speaking women. Sexual and Reproductive Healthcare, 11, 91-96. https://doi.org/10.1016/j. srhc.2016.10.001

Howarth, A. M., \& Swain, N. R. (2019). Skills-based childbirth preparation increases childbirth self-efficacy for first time mothers. Midwifery, 70, 100-105. https://doi.org/10.1016/j. midw.2018.12.017

Karlström, A., Nystedt, A., \& Hildingsson, I. (2015). The meaning of a very positive birth experience: Focus groups discussions with women. BMC Pregnancy and Childbirth, 15(1), 1-8. https://doi. org/10.1186/s12884-015-0683-0

Levett, K. M., Lord, S. J., Dahlen, H. G., Smith, C. A., Girosi, F., Downe, S., Finlayson, K. W., Fleet, J., Steen, M., Davey, M. A., Newnham, E., Werner, A., Arnott, L., Sutcliffe, K., Seidler, A. L., Hunter, K. E., \& Askie, L. (2020). The AEDUCATE Collaboration. Comprehensive antenatal education birth preparation programmes to reduce the rates of caesarean section in nulliparous women. Protocol for an individual participant data prospective meta-analysis. BMJ Open, 10(9), e037175. https://doi.org/10.1136/ bmjopen-2020-037175

Mukamurigo, J. U., Berg, M., Ntaganira, J., Nyirazinyoye, L., \& Dencker, A. (2017). 
Associations between perceptions of care and women's childbirth experience: A population-based cross-sectional study in Rwanda. BMC Pregnancy and Childbirth, 17(1), 1-7. https://doi. org/10.1186/s12884-017-1363-z

Neerland, C. E., Avery, M. D., Looman, W. S., Saftner, M. A., Rockwood, T. H., \& Gurvich, O. V. (2020). Development and Testing of the Preparation for Labor and Birth Instrument. JOGNN - Journal of Obstetric, Gynecologic, and Neonatal Nursing, 49(2), 200-211. https://doi. org/10.1016/j.jogn.2019.12.006

Puspasari, J., Nur Rachmawati, I., \& Budiati, T. (2018). Family support and maternal self-efficacy of adolescent mothers. Enfermeria Clinica, 28, 227-231. https://doi.org/10.1016/S1130 8621(18)30073-1

Sbrilli, M. D., Duncan, L. G., \& Laurent, H. K. (2020). Effects of prenatal mindfulnessbased childbirth education on childbearers' trajectories of distress: a randomized control trial. BMC Pregnancy and Childbirth, 20(1), 1-13. https://doi. org/10.1186/s12884-020-03318-8

Smarandache, A., Kim, T. H. M., Bohr, Y., \& Tamim, H. (2016). Predictors of a negative labour and birth experience based on a national survey of Canadian women. BMC Pregnancy and Childbirth, 16(1), 1-9. https://doi.org/10.1186/ s12884-016-0903-2

Ulfsdottir, H., Nissen, E., Ryding, E. L., LundEgloff, D., \& Wiberg-Itzel, E. (2014). The association between labour variables and primiparous women's experience of childbirth; a prospective cohort study. BMC Pregnancy and Childbirth, 14(1), 1-7. https://doi.org/10.1186/14712393-14-208

Waldenström, U., Hildingsson, I., Rubertsson, C., \& Rådestad, I. (2004). A negative birth experience: Prevalence and risk factors in a national sample. Birth, 31(1), 17-27. https://doi.org/10.1111/j.07307659.2004.0270.x 